JURNAL SYNTAX FUSION

Vol 1 No 11, November 2021

E-ISSN: 2775-6440 | P-ISSN: 2808-7208

Jurnal Homepage https://fusion.rifainstitute.com

\title{
PENGARUH UKURAN PERUSAHAAN, ARUS KAS OPERASIONAL, DAN NET PROFIT MARGIN (NPM) TERHADAP RETURN SAHAM
}

\author{
David Stepanus, Suklimah Ratih \\ Fakultas Ekonomi, Universitas Widya Kartika, Indonesia \\ Email: davidstefanus48@gmail.com,ratihratih177@gmail.com
}

\begin{abstract}
Return is a result obtained from an investment. In the research needed for investors to invest in order to minimize losses from investing, there are several factors that affect the size of the returns in the company. From the company as well as from external companies. Therefore this study aims to see the effect of Company Size, Operational Cash Flow, and Net Profit Margin (NPM) on Stock Returns in Automotive companies in 2015-2019.The sampling method in this study used purposive sampling so that the researchers found 11 companies that match the criteria in 2015-2019, so that the research analyzed was 55 samples. The testing technique in this research is in the form of classical assumption test, multiple linear regression analysis, coefficient determination test, and T test.The results showed that company size, operating cash flow and net profit margin did not have a significant effect on stock returns.
\end{abstract}

Keywords: Company Size; Operational Cash Flow; Net Profit Margin (NPM); Stock Return

\begin{abstract}
Abstrak
Return merupakan sebuah hasil yang diperoleh dari suatu investasi. Dalam berinvestasi diperlukan pengamatan bagi para investor dalam menanamkan modal agar dapat meminimalisir kerugian dari menanamkan modal, ada beberapa faktor yang mempengaruhi besar kecilnya return dalam perusahaan. Dari internal perusahaan maupun dari eksternal perusahaan. Oleh sebab itu penelitian ini bertujuan untuk mengetahui pengaruh Ukuran Perusahaan, Arus Kas Operasional, dan Net Profit Margin (NPM) terhadap Return Saham pada perusahaan Otomotif tahun 2015-2019. Metode pengambilan sampel dalam penelitian ini menggunakan purposive sampling sehingga peneliti mendapatkan 11 perusahaan yang sesuai kriteria pada tahun 2015-2019, sehingga penelitian yang dianalisis sebanyak 55 sampel. Teknik pengujian dalam penelitian ini berupa uji asumsi klasik, analisis regresi linier berganda, uji koefisien determinasi, dan uji T. Hasil penelitian yang menunjukkan bahwa Ukuran Perusahaan, Arus Kas Operasional, dan Net Profit Margin tidak berpengaruh secara signifikan terhadap Return Saham.
\end{abstract}

Kata Kunci: Ukuran Perusahaan; Arus Kas Operasional; Net Profit Margin (NPM); Return Saham

Diterima: 20-10-2021 Direvisi: 14-11-2021 Diterbitkan: 20-11-2021 


\section{Pendahuluan}

Dengan pesatnya perkembangan teknologi, industri otomotif juga mengalami pertumbuhan yang signifikan. Investor dapat berinvestasi di industri otomotif dengan berbagai cara. Salah satu investor dapat berinvestasi di pasar modal. Di era perkembangan bisnis yang semakin berkembang dewasa ini, pasar modal merupakan pasar bagi kegiatan perekonomian melalui proses jual beli obligasi, saham dan surat berharga lainnya. Efek digunakan untuk investasi, termasuk investasi jangka panjang dan investasi jangka pendek yang diterbitkan oleh perusahaan pemerintah atau swasta yang tercatat di Bursa Efek Indonesia (BEI). Bursa Efek Indonesia (BEI) merupakan tempat bagi perusahaan dan investor untuk membeli dan menjual efek. Menurut Rahmah, pasar modal merupakan sumber pembiayaan yang sangat dibutuhkan bagi pelaku usaha yang membutuhkan tambahan dana, serta alternatif pembiayaan bagi masyarakat (Mas Rahmah, 2019).

Fungsi pasar modal adalah sebagai alat untuk berinvestasi pada perusahaan yang terdaftar. Bagi perusahaan, pasar modal merupakan sarana untuk memperoleh pinjaman dari investor dan memberikan bukti sebagai imbalannya, yaitu saham perusahaan yang ditentukan. Saham merupakan alat yang digunakan untuk investasi, dan dapat juga dikatakan sebagai bukti bahwa investor menanamkan dana atau uangnya pada perusahaan. Tujuan investasi saham adalah untuk mendapatkan return atau keuntungan saham dari selisih harga jual dan harga beli (Darmawan, 2020).

Pengembalian saham adalah tingkat pengembalian bagi investor untuk membeli saham. Ada dua jenis return saham, yaitu return yang diharapkan dan return yang direalisasikan. Pengembalian yang diharapkan adalah pengembalian yang diharapkan investor di masa depan, tetapi mereka tidak mengetahui semua hasil yang diharapkan, dan pengembalian aktual adalah pengembalian modal yang telah terjadi, berdasarkan data historis. Ketika seorang investor melakukan investasi, investor harus mengamati dari laporan keuangan perusahaan. Laporan keuangan adalah laporan kegiatan dan hasil perusahaan yang mengeluarkan laporan tersebut (Wahyudiono, 2014).

Dalam laporan keuangan, ada total aset untuk melihat ukuran perusahaan, dan ada juga arus kas operasi, penjualan dan laba bersih yang menjadi margin laba bersih. Ukuran perusahaan merupakan diagram skala perusahaan yang dapat dinyatakan dengan total aset (Hery \& Si, 2017). Ukuran suatu perusahaan juga dapat dikatakan sebagai kekayaan perusahaan, yang dapat diukur dalam satuan rupiah atau mata uang yang berlaku. Ada juga arus kas operasi dalam laporan keuangan.Arus kas operasi adalah laporan yang menyatakan bahwa aktivitas operasi perusahaan mempengaruhi laba bersih perusahaan, karena arus kas operasi ini mencakup aktivitas operasi perusahaan. Dan ada tingkat laba bersih, yaitu rasio yang digunakan untuk melihat seberapa besar distribusi penjualan bersih perusahaan adalah laba bersih.

Objek penelitian ini adalah perusahaan otomotif. Dipilihnya perusahaan otomotif sebagai objek penelitian ini karena perkembangan industri di Indonesia khususnya perkembangan industri otomotif membuat persaingan perusahaan otomotif menjadi sangat ketat, dan permintaan masyarakat akan produk otomotif semakin meningkat. 
kendaraan bermotor khususnya pada perkembangan ini.Pada era sekarang ini masyarakat lebih banyak menggunakan kendaraan bermotor dibandingkan dengan berjalan kaki atau menggunakan angkutan umum untuk angkutan jarak dekat maupun jarak jauh (Gainan, J. 2010).

Sebuah artikel di oto.detik.com menjelaskan bahwa "Tingkat pertumbuhan mobil Indonesia meningkat secara signifikan dengan laju hampir $11,5 \%$ per tahun, sedangkan tingkat pertumbuhan ekonomi adalah 5\% per tahun." Pada saat yang sama, pemikiranrakyat.com Artikel itu menyebutkan, "Dibandingkan dengan pertumbuhan pembangunan infrastruktur jalan, pertumbuhan kendaraan (pribadi) cukup tinggi. Artinya (jalan raya) masih didominasi oleh pengguna mobil pribadi," menurut Kantor Berita Antara, Ricky dalam Oktober 2019 Bersabda di Bandung pada Senin 7th. Saat ini, 80\% penduduk menggunakan mobil pribadi, sedangkan hanya $20 \%$ penduduk yang menggunakan transportasi umum. Dari sisi perusahaan sendiri, dirasakan pertumbuhan pendapatan akan mencapai 6\% dari akhir 2018 hingga 2019. Mengutip dari Suara.com, "Konsumen Mobil dan Transportasi Perusahaan Melaporkan kinerja perusahaan pada 2019, kinerja menunjukkan pertumbuhan yang berkelanjutan. dari kinerja di akhir tahun 2018. Perseroan terus menjaga momentum pertumbuhannya. Pendapatan konsolidasi tahun 2019 meningkat 6\% atau Rp 16,8 triliun dibandingkan Rp 15,9 triliun pada periode yang sama tahun lalu."

\section{Metode Penelitian}

Populasi dalam penelitian ini adalah perusahaan otomotif yang terdaftar di Bursa Efek Indonesia tahun 2015-2019. Berdasarkan data yang diterbitkan oleh www.sahammilenial.com per November 2020, terdapat 13 perusahaan yang terdaftar dalam sektor Otomotif di BEI pada periode 2015-2019 (Amel, 2020).

Sampel adalah sebagian dari jumlah dan karakteristik yang dimiliki oleh populasi tersebut, maupun bagian kecil dari anggota populasi yang diambil menurut prosedur tertentu sehingga dapat mewakili populasinya. Sampel yang digunakan pada penelitian ini terdapat 11 perusahaan Otomotif yang terdaftar di Bursa Efek Indonesia tahun 20152019 yang sesuai dengan kriteria dari penelitian ini (Prihadi, 2019). Beberapa kriteria sampel yang digunakan dalam memilih sampel, yaitu:

1. Perusahaan otomotif yang terdaftar di Bursa Efek Indonesia selama lima tahun berturut-turut dari tahun 2015 sampai dengan tahun 2019

2. Perusahaan yang memiliki data-data laporan keuangan perusahaan otomotif dan informasi yang terkait dan yang dibutuhkan dalam penelitian ini.

\section{Teknik Analisis Data}

Sebelum melakukan teknik analisis data, peneliti perlu memperhitungkan variabel terlebih dahulu. Ada beberapa langkah untuk melakukan perhitungan yaitu:

1. Menghitung Ukuran Perusahaan pada Perusahaan Otomotif tahun 2015-2019

2. Menghitung Arus Kas Operasional pada Perusahaan Otomotif tahun 2015-2019

3. Menghitung Net Profit Margin pada Perusahaan Otomotif tahun 2015-2019

4. Menghitung Return Saham pada Perusahaan Otomotif tahun 2015-2019 


\section{Uji Asumsi Klasik}

Uji Asumsi Klasik dilakukan bertujuan untuk mengetahui hubungan variabel data. Uji asumsi klasik ini meliputi:

A. Uji Normalitas

Uji normalitas digunakan untuk menguji apakah dalam model regresi kedua variabel yang ada yaitu variabel bebas dan terikat mempunyai distribusi data yang normal atau tidak.

B. Uji Multikolinieritas

Uji multikolinearitas bertujuan untuk menguji apakah ada korelasi antara variabel bebas dalam model regresi. Model regresi yang baik seharusnya tidak memiliki korelasi antar variabel bebas. Metode untuk menguji adanya multikolinearitas dapat dilihat pada nilai tolerance dan variance inflammatory factor (VIF). Nilai toleransi dibatasi hingga 0,10 atau nilai VIF adalah 10,00. Jika VIF > 10.00 dan nilai tolerance $<0.10$, terdapat derajat multikolinearitas yang tinggi antara variabel independen dengan variabel independen lainnya.

C. Uji Autokorelasi

Uji autokorelasi digunakan untuk melihat terjadi autokorelasi atau tidaknya dengan cara menggunakan uji Durbin Watson, sebagai berikut:

a. DU < DW < 4-DU maka Ho diterima, artinya tidak terjadi autokorelasi.

b. DW < DL, atau DW > 4- DL maka Ho ditolak, artinya terjadi autokorelasi.

c. DL < DW < DU atau 4-DU, DW, 4- DL, artinya tidak ada kepastian atau kesimpulan yang pasti.

D. Uji Heteroskedastisitas

Lakukan uji heteroskedastisitas untuk mengetahui apakah data memiliki varians yang tidak sama atau data tersebut memiliki varians yang sama, yang disebut homoskedastisitas. Metode ini menggunakan scatter plot antara nilai prediksi standar (ZPRED) dan residual yang terpelajar (SRESID).

\section{Analisis Regresi Linier Berganda}

Regresi linier berganda adalah analisis dengan variabel bebas berganda. Teknik regresi linier berganda digunakan untuk mengetahui apakah dua atau lebih variabel bebas (X) berpengaruh signifikan terhadap variabel terikat (Y) (Roza, Fauzan, \& Rahayu, 2020). Analisis regresi berganda digunakan untuk menganalisis hubungan linier antara dua variabel $\mathrm{X}$ atau variabel ganda dan satu variabel $\mathrm{Y}$.

Rumus matematis dari analisis regresi berganda yang digunakan dalam penelitian ini adalah:

$$
Y=\alpha+\beta_{1} . X_{1}+\beta_{2} . X_{2}+\beta_{3} . X_{3}+e
$$

Keterangan:

$\mathrm{Y} \quad=$ Return Saham

$\mathrm{X}_{1} \quad=$ Ukuran Perusahaan

$\mathrm{X}_{2} \quad=$ Arus Kas Operasional

$\mathrm{X}_{3}=$ Net Profit Margin

$\alpha \quad=$ Konstanta. 
$B_{1}-\beta_{3}=$ Koefisien regresi

\section{Uji Koefisien Determinasi}

Koefisien determinasi dinyatakan dengan r2, umumnya dinyatakan dalam persentase (\%). Koefisien determinasi adalah nilai yang digunakan untuk mengukur kontribusi (kenaikan/penurunan) variabel bebas $(\mathrm{X})$ terhadap perubahan (peningkatan/penurunan) variabel terikat (Y). Dengan kata lain, variabel X adalah r2\%, dan sisanya dijelaskan oleh variabel lain. Variabel Y lainnya (sisanya) disebabkan oleh faktor lain yang juga mempengaruhi Y dan termasuk dalam kesalahan interferensi.

\section{Uji T}

Uji hipotesis Uji t merupakan uji hipotesis yang digunakan untuk mengetahui ada tidaknya perbedaan mean dari sampel yang dijadikan sampel, sehingga uji t disebut juga uji mean. Dalam pengujian ini digunakan untuk mengetahui apakah variabel $\mathrm{X}$ berpengaruh signifikan atau tidak signifikan terhadap variabel Y. Jika Tanda $<0,05$, terima Ha, dan jika Tanda > 0,05, tolak Ha..

\section{Hasil dan Pembahasan}

\section{Uji Asumsi Klasik}

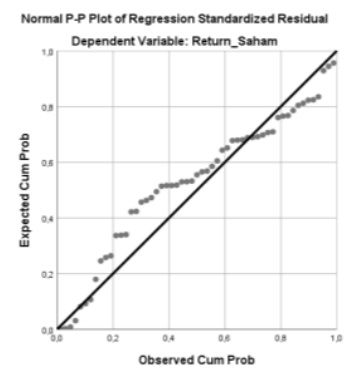

A. Uji Normalitas

Sumber: Diolah oleh peneliti

Berdasarkan gambar diatas menunjukkan bahwa data menyebar disekitar garis diagonal dan mengikuti arah diagonal, maka dapat dikatakan bahwa data penelitian adalah normal.

B. Uji Multikolinearitas

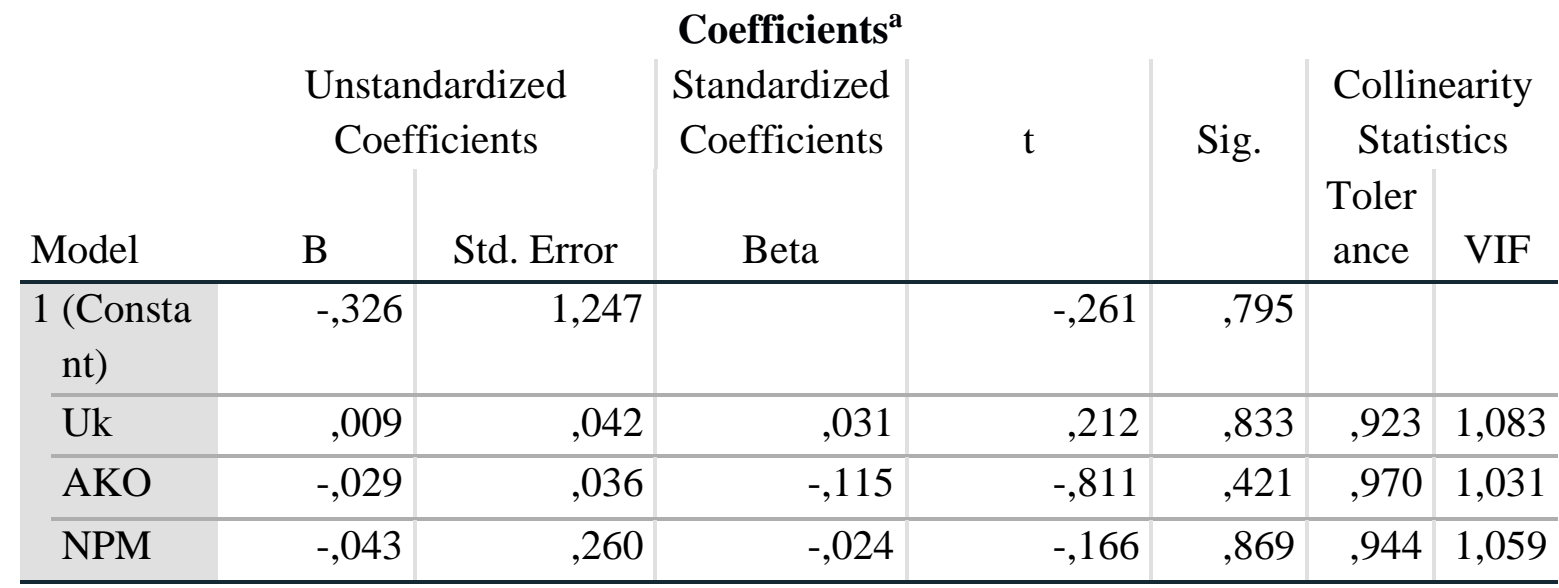


a. Dependent Variable: Return_Saham

Sumber: Diolah oleh peneliti

Dari tabel di atas dapat dilihat bahwa variance inflation factor (VIF) variabel ukuran perusahaan dengan SPSS adalah 1,083, arus kas operasi 1,031, dan rasio laba bersih 1,059 $<10,00$. Variabel skala nilai toleransi perusahaan menggunakan SPSS adalah 0,923, dan arus kas operasi 0,970, tingkat laba bersih 0,944>0,10, sehingga dapat disimpulkan bahwa tidak terdapat multikolinieritas pada ukuran perusahaan, arus kas operasi dan tingkat laba bersih.

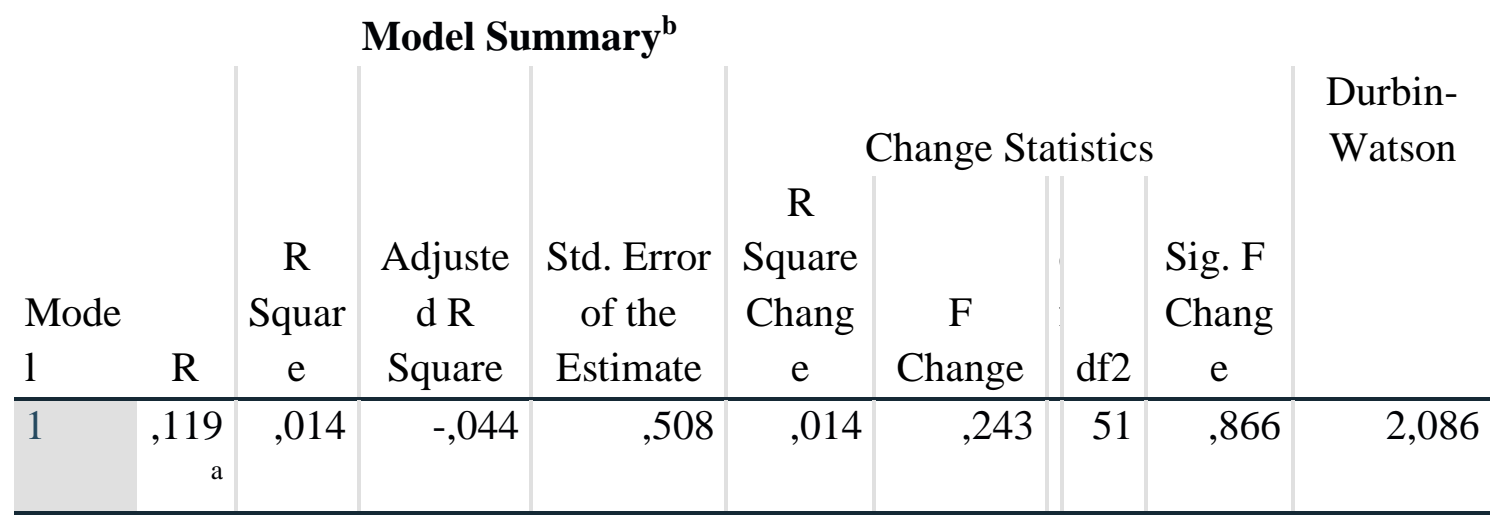

a. Predictors: (Constant), NPM, AKO, Uk

b. Dependent Variable: Return_Saham

C. Uji Autokorelasi

Sumber: Diolah oleh peneliti

$\mathrm{DU}<\mathrm{DW}<4-\mathrm{DU}$

$1,6815<2,086<4-1,6815$

$1,6815<2,086<2,3185$

Berdasarkan tabel diatas uji autokorelasi Durbin - Watson 2,086 yang akan dibandingkan dengan nilai tabel signifikansi 5\%. Jumlah sampel $\mathrm{N}=55$ dan jumlah variabel $3(K=3)$, maka diperoleh nilai DU 1,6815 < nilai DW 2,086 < 2,3185, sehingga dapat dikatakan bahwa tidak terjadi adanya autokorelasi dalam penelitian.

D. Uji Heteroskedastisitas

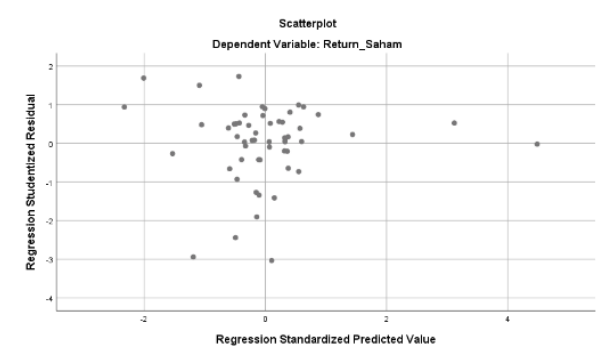

Sumber: Diolah oleh peneliti 
Berdasarkan gambar di atas, uji heteroskedastisitas menunjukkan bahwa titik-titik menyebar di atas dan di bawah angka 0. Selain itu, titik-titik tidak membentuk pola berbentuk gelombang, dan titik-titik tidak hanya mengelompok di atas atau di bawah. Dengan demikian dapat disimpulkan bahwa tidak terjadi heteroskedastisitas pada model regresi di atas.

\section{Analisis Regresi Linier Berganda}

\begin{tabular}{|c|c|c|c|c|c|c|}
\hline \multicolumn{7}{|c|}{ Coefficients $^{\mathbf{a}}$} \\
\hline & & \multicolumn{2}{|c|}{$\begin{array}{l}\text { Unstandardized } \\
\text { Coefficients }\end{array}$} & \multirow{2}{*}{$\begin{array}{c}\text { Standardized } \\
\text { Coefficients } \\
\text { Beta }\end{array}$} & \multirow[b]{2}{*}{$\mathrm{t}$} & \multirow[b]{2}{*}{ Sig. } \\
\hline \multicolumn{2}{|c|}{ Model } & B & Std. Error & & & \\
\hline 1 & (Constant) &,- 326 & 1,247 & &,- 261 & ,795 \\
\hline & Uk & ,009 & ,042 & ,031 & ,212 & ,833 \\
\hline & $\mathrm{AKO}$ &,- 029 & ,036 &,- 115 &,- 811 & ,421 \\
\hline & NPM &,- 043 & ,260 &,- 024 &,- 166 & ,869 \\
\hline
\end{tabular}

Sumber: Diolah oleh peneliti

Dari tabel diatas dimasukkan ke dalam rumus regresi linier berganda, yaitu: $Y=-0,326+0,009 \cdot X_{1}-0,029 \cdot X_{2}-0,043 \cdot X_{3}+e$

Sifat dari hubungan antara variabel $\mathrm{Y}$ dengan variabel $\mathrm{X}\left(\mathrm{X}_{1}, \mathrm{X}_{2}, \mathrm{X}_{3}\right)$ adalah konstan, hal ini dapat dilihat pada koefisien regresi bila (+) berarti perubahan $\mathrm{X}$ searah dengan perubahan $\mathrm{Y}$, bila sebaliknya bertanda (-) berarti antara X dan $\mathrm{Y}$ secara berlawanan perubahannya, sehingga dalam persamaan regresi diatas dapat diinterpretasikan sebagai berikut:

\section{Konstanta}

Nilai koefisien konstanta adalah sebesar -0,326 menyatakan apabila keseluruhan variabel $\mathrm{X}$ dalam penelitian ini sama dengan 0 (nol) maka besarnya return saham adalah $-0,326$.

2. Koefisien Regresi Ukuran Perusahaan $\left(X_{1}\right)$

Ukuran Perusahaan $\left(\mathrm{X}_{1}\right)$ merupakan variabel yang mempengaruhi return saham dengan koefisien regresi positif yaitu menunjukkan bahwa hubungan searah, jika variabel Ukuran Perusahaan $\left(\mathrm{X}_{1}\right)$ naik, maka return saham $(\mathrm{Y})$ juga akan naik sebesar 0,009. Dan sebaliknya jika Ukuran Perusahaan $\left(\mathrm{X}_{1}\right)$ mengalami penurunan maka return saham akan mengalami penurunan.

3. Koefisien Regresi Arus Kas Operasional $\left(\mathrm{X}_{2}\right)$

Arus Kas Operasional $\left(\mathrm{X}_{2}\right)$ merupakan variabel yang mempengaruhi return saham dengan koefisien regresi negatif yaitu menunjukkan bahwa hubungan berlawanan, jika variabel Arus Kas Operasional $\left(\mathrm{X}_{2}\right)$ naik, maka return saham (Y) akan mengalami penurunan sebesar 0,029. Dan sebaliknya jika Arus Kas Operasional $\left(\mathrm{X}_{2}\right)$ mengalami penurunan maka return saham akan mengalami kenaikan. 


\section{Koefisien Regresi Net Profit Margin $\left(\mathrm{X}_{3}\right)$}

Net Profit Margin (X3) merupakan variabel yang mempengaruhi return saham Koefisien regresinya negatif menunjukkan hubungan yang berlawanan, jika variabel Net Profit Margin (X3) meningkat maka return saham (Y) akan turun sebesar 0,043. Sebaliknya, jika margin laba bersih (X3) menurun, return saham akan meningkat.

\section{Uji Koefisien Determinasi}

Uji koefisien determinasi adalah sebuah penilaian yang mendekati satu berarti variabel $\mathrm{X}$ memberikan informasi yang dibutuhkan untuk memprediksi variasi variabel Y. Berdasarkan analisis autokorelasi diketahui nilai $\mathrm{R}$ sebesar 0,119 ini menunjukkan bahwa hubungan antara return saham dengan variabel $\mathrm{X}$ lemah karena di bawah 0,5. Sedangkan $\mathrm{R}^{2}$ sebesar 0,014 yang menunjukkan bahwa pengaruh variabel $\mathrm{X}$ terhadap variabel Y sebesar 1,4\% dan sisanya 98,6\% dipengaruhi oleh variabel-variabel di luar penelitian.

\section{Uji T}

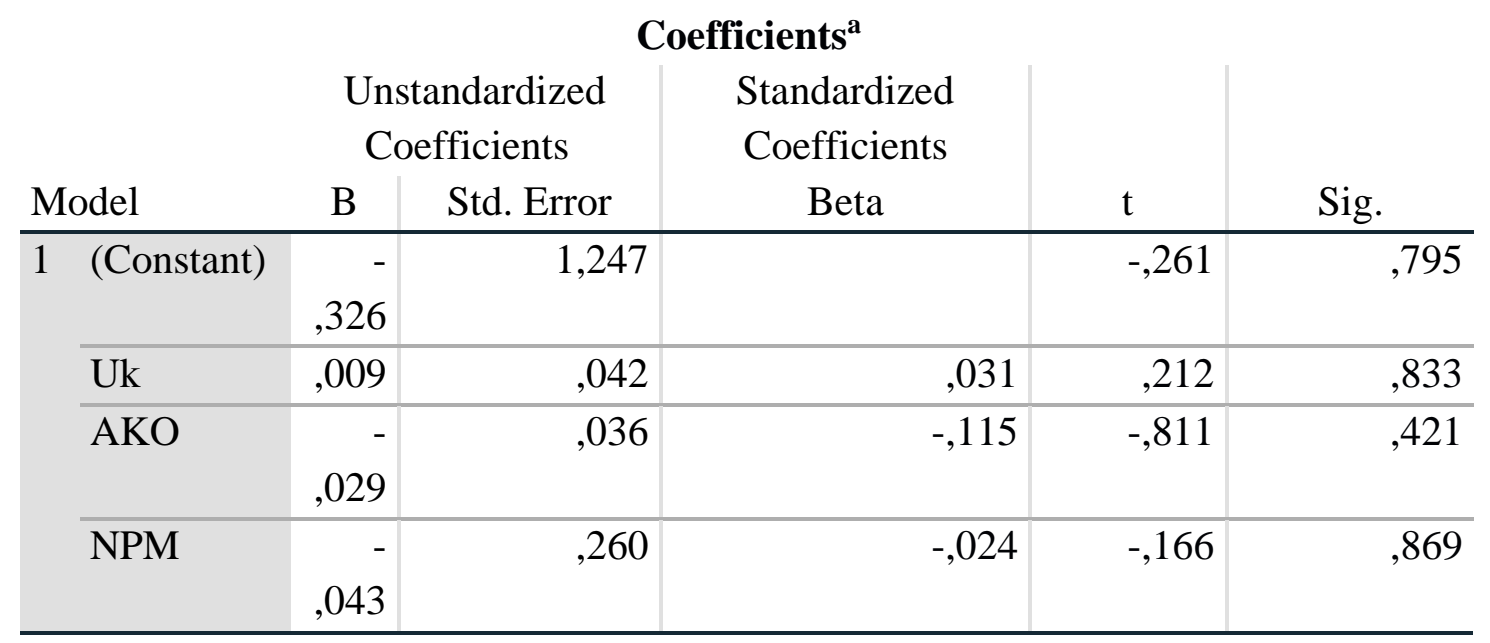

Sumber: Diolah oleh peneliti

Berdasarkan tabel diatas dapat disimpulkan bahwa:

1. Ukuran Perusahaan terhadap Return Saham

Berdasarkan Tabel diatas dapat diketahui bahwa nilai signifikan dari Ukuran Perusahaan sebesar 0,833 atau $83,3 \%$. Nilai tersebut lebih besar dari 0,05 atau $5 \%$ sehingga $\mathrm{H}_{1}$ ditolak. Hal ini dapat dikatakan bahwa variabel Ukuran Perusahaan tidak memiliki pengaruh terhadap Return Saham.

2. Arus Kas Operasional terhadap Return Saham

Berdasarkan Tabel diatas dapat dikatakan bahwa nilai signifikan dari Arus Kas Operasional sebesar 0,421 atau 42,1\%. Nilai tersebut lebih besar dari 0,05 atau 5\% sehingga $\mathrm{H}_{2}$ ditolak. Hal ini dapat dikatakan bahwa variabel Arus Kas Operasional tidak memiliki pengaruh terhadap Return Saham.

3. Net Profit Margin terhadap Return Saham

Berdasarkan Tabel diatas dapat diketahui bahwa nilai signifikan dari Net Profit Margin sebesar 0,869 atau 86,9\%. Nilai tersebut lebih besar dari 0,05 atau 5\% 
sehingga $\mathrm{H}_{3}$ ditolak. Hal ini dapat dikatakan bahwa variabel Net Profit Margin tidak memiliki pengaruh terhadap Return Saham.

\section{Pembahasan Penelitian}

\section{Pengaruh Ukuran Perusahaan terhadap Return Saham}

Hipotesis pertama (H1) penelitian ini menunjukkan bahwa ukuran perusahaan berpengaruh signifikan terhadap return saham PT Bursa Efek Indonesia periode 20152019, namun ditolak. Berdasarkan hasil penelitian dapat diketahui bahwa nilai signifikansi ukuran perusahaan adalah $0,833>0,05$.

Penelitian ini mendukung hasil Widiarini yang menunjukkan bahwa ukuran perusahaan tidak berpengaruh terhadap return saham (Widiarini \& Dillak, 2019). Hal ini menunjukkan bahwa total aset yang diumumkan dalam laporan keuangan 2015-2019 tidak menjadi perhatian investor dalam mengambil keputusan investasi. Artinya perusahaan besar tidak akan selalu memberikan return yang besar, dan perusahaan kecil juga bisa memberikan return yang tinggi kepada investor.

\section{Pengaruh Arus Kas Operasional terhadap Return Saham}

Hipotesis kedua (H2) penelitian ini menunjukkan bahwa arus kas operasi berpengaruh signifikan terhadap return saham PT Bursa Efek Indonesia tahun 2015 sampai 2019, namun ditolak. Berdasarkan hasil penelitian dapat diketahui bahwa nilai signifikansi Arus Kas Operasional adalah 0,421 > 0,05.

Penelitian ini mendukung hasil penelitian Ridha yang menunjukkan bahwa arus kas operasi tidak berpengaruh terhadap return saham (Ridha, 2019). Semakin besar arus kas operasi maka semakin besar kepercayaan investor terhadap investasi perusahaan, begitu juga sebaliknya. Namun hal ini menunjukkan bahwa arus kas operasi yang dipublikasikan tidak dipercaya oleh investor dalam berinvestasi, sehingga arus kas operasi tersebut tidak berdampak pada return saham..

\section{Pengaruh Net Profit Margin terhadap Return Saham}

Hipotesis ketiga $\left(\mathrm{H}_{3}\right)$ dalam penelitian ini menyatakan bahwa Net Profit Margin berpengaruh secara signifikan terhadap Return Saham pada perusahaan Otomotif di Bursa Efek Indonesia tahun 2015-2019, ditolak. Berdasarkan hasil penelitian dapat dilihat dari nilai signifikan Net Profit Margin sebesar 0,869>0,05.

Penelitian ini mendukung hasil penelitian dari Eko Widarta Utama yang menyatakan bahwa Net Profit Margin tidak berpengaruh terhadap Return Saham (Utama, 2018). Hal ini menunjukkan bahwa Net Profit Margin dari tahun 2015-2019 bukan menjadi perhatian para investor dalam mengambil keputusan untuk berinvestasi. Maka dapat dikatakan bahwa semakin besar atau semakin kecil Net Profit Margin dalam perusahaan belum tentu dapat menggeser naik ataupun turun dari nominal harga sebuah saham perusahaan.

\section{Kesimpulan}

Hasil penelitian ini menunjukkan bahwa ukuran perusahaan tidak berpengaruh signifikan terhadap return saham. Arus kas operasi tidak berpengaruh signifikan terhadap 
return saham. Pada saat yang sama, margin laba bersih tidak memiliki dampak yang signifikan terhadap imbal hasil saham.

Bagi perusahaan otomotif, penelitian ini dapat dijadikan sebagai bahan pertimbangan untuk kedepannya dalam laporan keuangan perusahaan. Sedangkan untuk investor, Anda dapat mempertimbangkan penelitian ini, dan Anda dapat melihat faktorfaktor lain yang mempengaruhi return saham, termasuk faktor internal dan eksternal lainnya. Bagi peneliti selanjutnya, penelitian ini dapat melihat bahwa koefisien determinasi variabel seperti ukuran perusahaan, arus kas operasi, dan margin laba bersih dari hasil penelitian adalah 1,4\%, sehingga dapat dilihat bahwa selain variabel untuk melihat saham Efek lain dari pendapatan. 


\section{BIBLIOGRAFI}

Amel. (2020, February 21). Daftar Perusahaan Manufaktur yang Terdaftar di BEI. Saham Milenial. https://sahammilenial.com/daftar-perusahaan-manufaktur-yangterdaftar-di-bei/

Darmawan, M. (2020). Dasar-dasar Memahami Rasio dan Laporan Keuangan. UNY Press. Google Scholar

Gainan, J. (2010). Cara Mudah Memahami Istilah Investasi. Jakarta Selatan: Hikmah (PT Mizan Publika).

Hery, S. E., \& Si, M. (2017). Kajian Riset Akuntansi. Jakarta: PT Grasindo. Google Scholar

Mas Rahmah, S. H. (2019). Hukum Pasar Modal. Prenada Media. Google Scholar

Prihadi, Toto. (2019). Analisis Laporan Keuangan. Gramedia Pustaka Utama. Google Scholar

Ridha, M. Arsyadi. (2019). Pengaruh Rasio Keuangan, Ukuran Perusahaan, dan Arus Kas Operasi terhadap Harga Saham Syariah. JIA (Jurnal Ilmiah Akuntansi), 4(2), 184200. Google Scholar

Roza, Rahmi, Fauzan, Mohamad Nurkamal, \& Rahayu, Woro Isti. (2020). Tutorial Sistem Informasi Prediksi Jumlah Pelanggan Menggunakan Metode Regresi Linier Berganda Berbasis Web Menggunakan Framework Codeigniter. Kreatif. Google Scholar

Utama, Eko Widarta. (2018). Pengaruh Net Profit Margin Terhadap Harga Saham Pt. Unilever Tbk Tahun 2011-2016. Jurnal Mitra Manajemen, 2(1), 35-43. Google Scholar

Wahyudiono, Bambang. (2014). Mudah membaca laporan keuangan. Jakarta: Raih Asa Sukses, 2014, 26-90. Google Scholar

Widiarini, Syafira, \& Dillak, Vaya Julliana. (2019). Pengaruh Profitabilitas, Leverage, Likuiditas, Kebijakan Dividen, Dan Ukuran Perusahaan Terhadap Return Saham (Studi Kasus Pada Perusahaan Sektor Properti, Real Estate, Dan Konstruksi Bangunan Yang Terdaftar Di Bursa Efek Indonesia Periode 2013-2017). Jurnal Ilmu Sosial Politik Dan Humaniora, 2(2), 1-14. Google Scholar

First publication right:

Jurnal Syntax Fusion: Jurnal Nasional Indonesia

This article is licensed under:

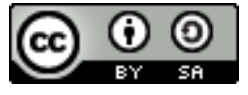

